\title{
Segregation analysis for bacterial leaf blight disease resistance genes in rice 'MR219' using SSR marker
}

\author{
Zakiah Mohd Zuki', Mohd Y. Rafii ${ }^{12^{*}}$, Asfaliza Ramli ${ }^{3}$, Yusuff Oladosu², Mohammad Abdul Latif ${ }^{1}$, \\ Kamaruzaman Sijam ${ }^{1}$, Mohd Razi Ismail ${ }^{2}$, and Hamidah Mohd Sarif ${ }^{1}$
}

\author{
${ }^{1}$ Universiti Putra Malaysia, Faculty of Agriculture, 43400 UPM Serdang, Selangor, Malaysia. \\ ${ }^{2}$ Universiti Putra Malaysia, Institute of Tropical Agriculture and Food Security, 43400 UPM Serdang, Selangor, Malaysia. \\ *Corresponding author (mrafii@upm.edu.my). \\ ${ }^{3}$ Malaysian Agriculture Research and Development Institute, 13200 Seberang Perai, Pulau Pinang, Malaysia.
}

Received: 21 October 2019; Accepted: 15 January 2020; doi:10.4067/S0718-58392020000200227

\begin{abstract}
Bacterial leaf blight (BLB) caused by Xanthomonas oryzae pv. oryzae is one of the major hindrances in rice (Oryza sativa L.) production across the world including Malaysia. Therefore, the development of disease-resistant varieties remains a very economical and effective method of controlling BLB in rice. Based on this background, this study was conducted to analyze segregation pattern of simple-sequence repeat (SSR) markers associated with BLB resistance genes in an $F_{2}$ bulk population derived from a resistant variety (IRBB60) and a susceptible variety (MR219). Out of 129 simple sequence repeat (SSR) markers screened, 18 distinct polymorphism markers including R-gene based markers were used to screen $345 \mathrm{~F}_{2}$ progenies for resistance to BLB. Among the polymorphic markers, the chi-square analyses showed that 15 SSR markers (i.e. RM13 (xa5), RM21 (Xa21), RM122 (xa5), RM153 (xa5), RM164 (Xa13), RM206 (Xa10), RM5509, RM20B, RM25, RM163, RM169, RM218, RM267, RM276, and RM334) had a segregation ratio of $1: 2: 1$ for a single gene model $(\mathrm{df}=2.0, p \leq 0.05)$. For phenotypic ratio, the $\mathrm{F}_{2}$ population segregated in ratio $3: 1(\mathrm{R}: \mathrm{S})$ for resistant and susceptible plants, respectively. This indicated that resistance to BLB caused by pathotype $X$. oryzae pv. oryzae (Xoo) in the 'MR219' $\times$ 'IRBB60' $\mathrm{F}_{2}$ population is controlled by single dominant genes. The result presented in this study will help breeders to further breeding research in rice by enabling selection based on the genotype rather than on the phenotype. Similarly, the markers reported in this study will serve as a valuable tool for marker-aided selection for BLB resistance gene.
\end{abstract}

Key words: Disease resistance, $\mathrm{F}_{2}$ bulk population, Oryza sativa, rice bacterial leaf blight, simple sequence repeat.

\section{INTRODUCTION}

Rice (Oryza sativa L.) is one of the most important staple food that constitutes a large portion of a world standard diet. In spite of its position among the highly rated crops, the geometric growth rate of the global population has called stepping up the current yield for this important crop (Oladosu et al., 2018). In Malaysia, it was estimated that individuals consume $80 \mathrm{~kg}$ rice per year which amounts to $26 \%$ of the total daily caloric intake. At the moment, the self-sufficient in rice stands at $67 \%$ while the remaining 33\% shortfall under importation primarily from Pakistan, Vietnam, and Thailand. Despite the high level of government intervention on rice cultivation, the production output is not adding up, which is largely due to the susceptibility of local high yielding varieties to different diseases. The selection and hybridization for yield, yield component, and grain quality traits have led to improvement and release of new rice variety. However, this improvement has led to a gradual loss of genes responsible for biotic and abiotic tolerance. Similarly, the development of high N-receptive new rice varieties has a detrimental effect on pest and disease resistance. Among these diseases, bacterial 
leaf blight (BLB) caused by Xanthomonas oryzae pv. oryzae is considered one of the most devastating that cause severe yield losses (Chukwu et al., 2019a). Infection of plants at an early stage can cause up to 50\% yield while 20\%-40\% yield reduction was reported at the maximum tillering stage of infection (Chukwu et al., 2019a). In Malaysia, the recent BLB outbreak was reported to cause 50\%-70\% yield losses (Rafidah et al., 2018). These losses could jeopardize national food security and therefore, it is important to discover the solution to this problem.

This disease occurs at different growth stages and it is characterized by acute wilting of young plants. The pathogen causing leaf blight enters the plant through the wounded part of the plant or water pores. Lesions start as a small spot at the tip of the leaf with wavy margins as the water pores are located at the margins of upper parts of the leaf which later increase in size and gradually turn the leaf to yellow and later death of the plant (Yasmin et al., 2017). Various management strategies were conducted over the years to control this disease. In the past, various disease management strategies have been employed to avoid disease epidemics and reduce yield losses worldwide including Malaysia. Controlling BLB pathogen using chemical application and biological control is not very effective due to variation in sensitivity of pathogenic races. Additionally, due to the toxic residual effect, the use of chemical and antibiotics against BLB has been a major setback plant (Yasmin et al., 2017). Therefore, the development of resistant varieties is the economical, effective and eco-friendly strategy, for controlling this endemic pathogen to minimize disease incidence and yield losses (Chukwu et al., 2019b).

More than 32 bacterial blight resistance genes in a series from Xal to Xa34 has been discovered, identified and designated as reported by Ram et al. (2010). Marker-assisted selection (MAS) using simple sequence repeat (SSR) marker was selected as molecular markers for the present study due to its co-dominant nature which can detect both heteroand homozygous alleles. SSR markers can be efficiently applied for developing unique DNA profiles of rice genotypes because have a high level of polymorphism and greater information (Chukwu et al., 2019b).

Because MR219 is the most cultivated rice variety in Malaysia, covering almost 70\% to $90 \%$ of the cultivated areas as at the time of release in 2002 (Oladosu et al., 2014), efforts are constantly being made to increase its yield potentials. 'MR219' have good characteristics including high yield ( 7 to $10 \mathrm{t} \mathrm{ha}^{-1}$ ), average maturation period (105 to $111 \mathrm{~d}$ ), intermediate amylose content (21.4\%), long and slender grains and moderate resistance to blast, BLB and brown planthopper (BPH) (Bashar et al., 2014). Unfortunately, after years of intensive cultivation, this variety began to show more susceptibility to bacterial blight disease. While the donor parent 'IRBB60', carrying four BLB resistance genes namely Xa4, $x a 5$, $x a 13$, and $\mathrm{Xa21}$, is widely grown rice variety developed by International Rice Research Institute, Philippines (IRRI, 2002). According to Shanti et al. (2010), 'IRBB60' was successful in the parental lines of hybrid rice KMR3 and PRR78. At the moment, BLB is a major problem in rice production in Malaysia, and no resistant variety is available for commercial cultivation. Hence, the objective of this study was to analyze the segregation pattern of SSR markers associated with BLB resistance genes in an $\mathrm{F}_{2}$ bulk population derived from IRBB60 (resistant variety) and MR219 (susceptible variety).

\section{MATERIALS AND METHODS}

\section{Plant materials}

Three hundred and forty-five $\mathrm{F}_{2}$ hybrid rice population derived from a cross between a local rice variety MR219 (susceptible variety) and IRBB60 (resistant variety) were genotyped with selected SSR markers associated with BLB resistance gene. 'MR219' was sourced from the gene bank at the Malaysian Agricultural Research and Development Institute (MARDI), while 'IRBB60' was collected from the International Rice Research Institute (IRRI), Philippines.

\section{Genomic DNA segregation}

Three-week-old seedlings were used for the genomic DNA extraction, from where $0.5 \mathrm{~g}$ young leaf were excised from the growing plant. Modified CTAB method by Oladosu et al. (2015) was adopted in this experiment for the DNA extraction. Young leaves were cut into small pieces before grinding into fine powder using mortar and pestle in 0.3 to $0.4 \mathrm{~mL}$ liquid nitrogen and transferred into micro-centrifuge $2.0 \mathrm{~mL}$ Eppendorf tube. After that, $500 \mu \mathrm{L} 2$ x CTAB buffer $(40.91 \mathrm{~g} \mathrm{NaCl}$; $1 \mathrm{M}$ Tris-HCl, $\mathrm{pH}$ 8.0; 0.5 M EDTA, and $100 \mu \mathrm{L} \beta$-mercaptoethanol) were added and mixed thoroughly. The samples were then incubated at $65^{\circ} \mathrm{C}$ for $1 \mathrm{~h}$ in a water bath to breakdown the cell such as carbohydrate and protein. Then, the supernatant was transferred into a new tube and $500 \mu \mathrm{L}$ chloroform-isoamyl alcohol (24:1) were added. The samples 
were then centrifuged at $14000 \mathrm{rpm}$ for $5 \mathrm{~min}$ at $4{ }^{\circ} \mathrm{C}$ using centrifuge (5430 R, Eppendorf, Hamburg, Germany). The supernatant aqueous layer was then transferred to a new $2.0 \mathrm{~mL}$ Eppendorf tube and $500 \mu \mathrm{L}$ isopropanol were added. The samples were again incubated at $-20^{\circ} \mathrm{C}$ overnight. After that, the samples were centrifuged at $14000 \mathrm{rpm}$ for $5 \mathrm{~min}$ at $4{ }^{\circ} \mathrm{C}$ and the isopropanol discarded and DNA pellet remain was washed with $500 \mu \mathrm{L} 70 \%$ ethanol. Then, the pellets were air-dried at room temperature. The DNA pellet was dissolved in $100 \mu \mathrm{L} \mathrm{TE}$ buffer $(1 \mathrm{M}$ Tris-HCl, $\mathrm{pH} 8.0$; and 0.5 M EDTA). Then, $1.0 \mu \mathrm{L}$ RNase $\left(10 \mathrm{mg} \mathrm{mL}^{-1}\right)$ was added to remove the enzyme. The samples were incubated at $37^{\circ} \mathrm{C}$ for 30 min and $10 \mu \mathrm{L}(1 / 10)$ sodium acetate and $200 \mu \mathrm{L}, 2$ volume of absolute ethanol was added and stand overnight. Then, the samples were centrifuged at $14000 \mathrm{rpm}$ for $5 \mathrm{~min}$. After that, the supernatant was discarded and the DNA pellets were again rinsed with $500 \mu \mathrm{L} \mathrm{70 \%} \mathrm{ethanol} \mathrm{and} \mathrm{the} \mathrm{pellets} \mathrm{were} \mathrm{air-dried} \mathrm{for} 1 \mathrm{~h}$. The DNA pellet was then dissolved in $100 \mu \mathrm{L}$ TE buffer before final centrifuged for $5 \mathrm{~min}$ at $5000 \mathrm{rpm}$. The DNA quality was checked using nano-drop spectrophotometer machine (NanoDrop 1000, Thermo Fisher Scientific,Waltham, Massachusetts, USA) and analyzed purity with $1 \%$ agarose gel by electrophoresis. After adjusting final concentrations to $50 \mathrm{ng} \mu \mathrm{L}^{-1}$, the stock solution was stored at $-20{ }^{\circ} \mathrm{C}$ and the working solution at $4{ }^{\circ} \mathrm{C}$.

\section{Microsatellite DNA markers for SSR amplification}

A total of 129 primers sets from Gramene database (www.gramene.org) and previous studies associated with bacterial leaf blight resistance gene (Chu et al., 2006; Iyer-Pascuzzi and McCouch, 2007) were used for screening both parents to determine the efficient and polymorphic primers.

\section{Polymerase chain reaction (PCR) and genotypic screening for marker segregation}

PCR reactions were performed in a total volume of $15 \mu \mathrm{L}$ containing $2.0 \mu \mathrm{L}$ genomic DNA, $1.0 \mu \mathrm{L}(5 \mathrm{mM})$ of each forward and reverse primer, $3.0 \mu \mathrm{L}\left(1 \mathrm{mM}\right.$ ) dNTPs, $1.5 \mu \mathrm{L}$ (5x) buffer (green go tag and colorless go taq), $0.8 \mu \mathrm{L}(25 \mathrm{mM}) \mathrm{MgCl}_{2}$, $0.1 \mu \mathrm{L}$ DNA Taq polymerase, and $4.1 \mu \mathrm{L}$ nuclease-free water. The PCR products were amplified using Mastercycler gradient machine (Eppendorf) with an initial denaturing for $94{ }^{\circ} \mathrm{C}$ for $5 \mathrm{~min}$ followed by 35 cycles of the polymerization reaction with $30 \mathrm{~s}$ at $94^{\circ} \mathrm{C}$ denaturing, $30 \mathrm{~s}$ primer annealing at either 54,55 or $60{ }^{\circ} \mathrm{C}$ (depending on the primer pair), and $1 \mathrm{~min}$ at $72{ }^{\circ} \mathrm{C}$ for primer extension, followed by a final extension step at $72{ }^{\circ} \mathrm{C}$ for $1 \mathrm{~min}$ by rapid cooling to $4{ }^{\circ} \mathrm{C}$ prior to analysis. The PCR products were loaded on the gel electrophoresis machine, $5 \mu \mathrm{L}$ of each PCR products were loaded on a $2.0 \%$ agarose gel stained with ethidium bromide in $1 \times \mathrm{TBE}$ buffer. The gel was run at a constant voltage of $80 \mathrm{~V}$ for $1 \mathrm{~h}$ and gel picture was visualized under UV light and documented using the Bio-Rad molecular imager (Molecular Imager Gel Doc XR System, Bio-Rad Laboratories, Hercules, California, USA). The 100 bp DNA ladder was used for scoring of bands in each gel. The size bands scoring was done according to the size of the DNA ladder already defined by ChemiDoc with Image Lab Software (Bio-Rad). Based on the band obtained from the Gel Doc image analyzer, the progenies were scored with respect to similarity with the two-parent. The resistant parent (IRBB60) was scored (R) while the susceptible parent (MR219) was scored as (S), however, heterozygote progenies are scored as (H) which indicated genotypic resemble with both 'IRBB60' and 'MR219'.

\section{Phenotypic screening in the $F_{2}$ population}

Field evaluation and screening of $\mathrm{F}_{2}$ were carried out after $60 \mathrm{~d}$ of transplanting. The leaf blades were inoculated with the BLB pathogen Xanthomonas oryzae pv. oryzae (Xoo) following the protocol described by Kauffman et al. (1973), where $3 \mathrm{~cm}$ below the leaf tips were cut using scissors. For inoculation, the inoculum of high virulence pathogen (pathotype Xoo $\mathrm{P}_{7.0}$ ) was used in this study provided by Pest and Diseases Laboratory in MARDI Seberang Perai, Penang. The pathotype was cultured $48 \mathrm{~h}$ before inoculation. Scoring and recording were done $30 \mathrm{~d}$ after inoculation. The plants were evaluated for BLB resistance by measuring the length of lesions and the leaf length based on the Standard Evaluation System (SES) recommended by IRRI. Data were recorded as resistant if lesion length was less than $5 \mathrm{~cm}$ and described as susceptible if lesion length was more than $5 \mathrm{~cm}$.

\section{Statistical analysis}

Data for the segregation pattern were tested using chi-square $\left(\chi^{2}\right)$ analysis. This analysis for the phenotypic and genotypic ratio was calculated using the chi-square formula, $\chi^{2}=(O-E)^{2} / E$, where $E$ is expected value and $O$ is the observed value 
(Ashkani et al., 2011). For the single-gene model, it was considered as significant $(p \leq 0.05)$ if chi-square value was greater than $5.99(\mathrm{df}=2)$ for genotypic, and $3.84(\mathrm{df}=1)$ for phenotypic ratio. The genotypic ratio by chi-square analysis was tested against the expected Mendelian ratio (1:2:1), while the phenotypic ratio for the goodness fit of $3: 1$.

\section{RESULTS AND DISCUSSION}

\section{Microsatellite DNA marker screening of parental lines and $F_{2}$ population}

Out of 129 SSR primers screened only $42(33 \%)$ markers showed clear polymorphism between BLB resistant and susceptible to parental lines. Among 42 primers, 18 best polymorphic SSR markers including gene-based markers were evaluated on the $345 \mathrm{~F}_{2}$ progenies derived from MR219 $\times$ IRBB60 (Table 1). The patterns of all the markers were similar to segregation ration of 1:2:1 except for 3 markers (RM400, RM264, and RM281). Figure 1 showed the banding pattern of polymorphic SSR markers related to BLB genes, RM206 with 22 samples and two parents. Band photo was taken after running the gel electrophoresis on $2 \%$ agarose gel stained with ethidium bromide.

\section{Marker segregation data analysis}

The observed segregation ratio for BLB resistance and susceptibility in $\mathrm{F}_{2}$ progenies for 18 polymorphic microsatellite DNA markers is presented in Table 2 . The chi-square analysis $\left(\chi^{2}\right)$ showed a good fit to expected Mendelian segregation ratio (1:2:1) for 15 SSR markers, RM13, RM21, RM122, RM153, RM164, RM206, RM5509, RM20B, RM25, RM163,

Table 1. Information on the 18 best polymorphic SSR markers used for segregation study in rice.

\begin{tabular}{|c|c|c|c|c|c|}
\hline $\mathrm{Nr}$ & SSR primers & $\mathrm{Chr}$ & Primer sequence (forward) & Primer sequence (Reverse) & $\begin{array}{l}\text { Expected } \\
\text { size (bp) }\end{array}$ \\
\hline 1 & RM164 (Xa13) & 5 & F: TCTTGCCCGTCACTGCAGATATCC & R: GCAGCCCTAATGCTACAATTCTTC & 246 \\
\hline 2 & RM206 (Xa10) & 11 & F: CCCATGCGTTTAACTATTCT & R: CGTTCCATCGATCCGTATGG & 147 \\
\hline 3 & RM21 (Xa21) & 11 & F: ACAGTATTCCGTAGGCACGG & R: GCTCCATGAGGGTGGTAGAG & 157 \\
\hline 4 & RM153(xa5) & 5 & F: GCCTCGAGCATCATCATCAG & R: ATCAACCTGCACTTGCCTGG & 201 \\
\hline 5 & RM400 (xa33) & 6 & F: ACACCAGGCTACCCAAACTC & R: CGGAGAGATCTGACATGTGG & 321 \\
\hline 6 & RM13 (xa5) & 5 & F: TCCAACATGGCAAGAGACAG & R: GGTGGCATTCGATTCCAG & 141 \\
\hline 7 & RM5509 (xa33) & 6 & F: GATGATCCATGCTTTGGCC & R: TTCCAGCAGAAAGAAGACGC & 255 \\
\hline 8 & RM122 (xa5) & 5 & F: GAGTCGATGTAATGTCATCAGTGC & R: GAAGGAGGTATCGCTTTGTTGGAC & 227 \\
\hline 9 & RM20B & 11 & F: ATCTTGTCCCTGCAGGTCAT & R: GAAACAGAGGCACATTTCATTG & 140 \\
\hline 10 & RM25 & 8 & F: GGAAAGAATGATCTTTTCATGG & R: CTACCATCAAAACCAATGTTC & 146 \\
\hline 11 & RM163 & 5 & F: ATCCATGTGCGCCTTTATGAGGA & R: CGCTACCTCCTTCACTTACTAGT & 124 \\
\hline 12 & RM169 & 5 & F: TGGCTGGCTCCGTGGGTAGCTG & R: TCCCGTTGCCGTTCATCCCTCC & 167 \\
\hline 13 & RM218 & 3 & F: TGGTCAAACCAAGGTCCTTC & R: GACATACATTCTACCCCCGG & 148 \\
\hline 14 & RM264 & 8 & F: GTTGCGTCCTACTGCTACTTC & R: GATCCGTGTCGATGATTAGC & 178 \\
\hline 15 & RM267 & 5 & F: TGCAGACATAGAGAAGGAAGTG & R: AGCAACAGCACAACTTGATG & 156 \\
\hline 16 & RM276 & 6 & F: CTCAACGTTGACACCTCGTG & R: TCCTCCATCGAGCAGTATCA & 149 \\
\hline 17 & RM281 & 8 & F: ACCAAGCATCCAGTGACCAG & R: GTTCTTCATACAGTCCACATG & 138 \\
\hline 18 & RM334 & 5 & F: GTTCAGTGTTCAGTGCCACC & R: GACTTTGATCTTTGGTGGACG & 182 \\
\hline
\end{tabular}

Figure 1. SSR primer of RM206 showing the banding patterns in $F_{2}$ progenies derived from cross $M R 219 \times$ IRBB60 linked to bacterial leaf blight (BLB) resistance genes.



L: 100 bp ladder, S: susceptible to BLB, R: resistant to BLB, H: heterozygous, 1-22 lanes: $F_{2}$ progenies. 
RM169, RM218, RM267, RM276, and RM334, for a single gene model ( $\mathrm{df}=2.0, p \leq 0.05: 5.99)$. Other markers accept the hypothesis with significant difference $(p \leq 0.05$ and $p \leq 0.01)$ and did not fit the expected segregation ratios. From previous studies, McCouch et al. (1996) revealed two microsatellites markers RM122 and RM13 related to xa5 resistance gene. Other study on blast also supported with finding whereas genetic analyses on polymorphic simple sequence repeat (SSR) markers on $\mathrm{F}_{2}$ population derived from the cross of Pongsu Seribu 2 (resistant) and Mahsuri (susceptible) with good fit of 1:2:1 ratio for single-gene model (Ashkani et al., 2012).

\section{Phenotypic screening for $B L B$ resistance in $F_{2}$ population}

Scoring data for the length of lesion (LL) for BLB of $F_{2}$ plants were scored according to Kauffman et al. (1973) while for percentage diseased leaf area (\%DLA) were categorized according to Standard Evaluation System (SES) from IRRI (2002). Pathogenicity assay in Table 3 showed the expected and observed segregation ratios of resistant and susceptible plants in the $\mathrm{F}_{2}$ population inoculated with pathotype Xoo $\mathrm{P}_{7.0}$. The results revealed that $\mathrm{F}_{2}$ population with $\chi^{2} 1.18$ and 0.3055 probability segregated in a 3:1 (R:S) ratio for resistant and susceptible plants followed a single gene model ( $\mathrm{df}=1.0, p \leq 0.05)$, respectively. This indicates that resistance to BLB caused by pathotype Xoo $\mathrm{P}_{7.0}$ in $\mathrm{F}_{2}$ population was most likely controlled by single dominant genes. This result agreed with the previous study in blast disease resistance genes in a segregating $\mathrm{F}_{2}$ population of rice (Ashkani et al., 2011). In previous studies, two or more BLB R-gene were found very effective method against BLB isolates from the rice-growing region of the world (Chukwu et al., 2019a). Similarly, studies revealed that pyramiding lines of 'IRBB60' are resistant to all the Philippines races and the Punjab isolates of Xoo (Singh et al., 2001).

Table 2. Marker analysis in $F_{2}$ progenies derived from crossing between MR219 × IRBB60.

\begin{tabular}{lcccccc}
\hline & & \multicolumn{3}{c}{ Marker analyzed } & & \\
\cline { 2 - 5 } Markers & Chromosome & $\mathrm{RR}=\mathrm{R}$ & $\mathrm{Rr}=\mathrm{H}$ & $\mathrm{rr}=\mathrm{S}$ & $\chi^{2}(1: 2: 1)$ & Probability \\
\hline RM13 (xa5) & 5 & 93 & 175 & 77 & 1.56 & 0.4584 \\
RM21 (Xa21) & 11 & 90 & 176 & 79 & 0.84 & 0.6570 \\
RM122 (xa5) & 5 & 92 & 155 & 98 & 3.76 & 0.1526 \\
RM153 (xa5) & 5 & 75 & 181 & 89 & 1.97 & 0.3734 \\
RM164 (Xa13) & 5 & 100 & 172 & 73 & 4.23 & 0.1206 \\
RM206 (Xa10) & 11 & 90 & 176 & 79 & 0.84 & 0.6570 \\
RM400 & 6 & 69 & 193 & 83 & $6.01 *$ & 0.0495 \\
RM5509 & 6 & 74 & 189 & 82 & 3.53 & 0.1712 \\
RM20B & 11 & 95 & 174 & 76 & 2.12 & 0.3465 \\
RM25 & 8 & 80 & 179 & 86 & 0.69 & 0.7047 \\
RM163 & 5 & 96 & 174 & 75 & 2.58 & 0.2753 \\
RM169 & 5 & 90 & 172 & 83 & 0.29 & 0.8653 \\
RM218 & 3 & 183 & 85 & 1.65 & 0.4382 \\
RM264 & 77 & 192 & 63 & $8.63 * *$ & 0.0134 \\
RM267 & 8 & 160 & 95 & 1.96 & 0.3753 \\
RM276 & 5 & 90 & 157 & 91 & 2.99 & 0.2242 \\
RM281 & 6 & 97 & 190 & 63 & $8.43 * *$ & 0.0148 \\
RM334 & 8 & 84 & 83 & 0.36 & 0.8353 \\
\hline
\end{tabular}

$*$, **Significant at the 0.05 and 0.01 probability levels, respectively $\left(\mathrm{df}=2.0 ; \chi^{2}=5.99\right)$.

R: Resistant; S: susceptible; H: segregant; RR: plants with a banding pattern alike to the resistant parent alleles; Rr: heterozygous plants; rr: plants with a banding pattern alike to the susceptible parent alleles; $\chi^{2}$ : actual value of the chi-square test for resistant/susceptible ratio.

Table 3. Expected and observed segregation ratios of resistant and susceptible plants in $F_{2}$ population inoculated with pathotype Xoo P7.0 of Xanthomonas oryzae pv. oryzae for the genetic cross between MR219 × IRBB60.

\begin{tabular}{llcccc}
\hline & & \multicolumn{2}{c}{ Pathogenicity test } & & \\
\cline { 3 - 4 } Generation & Reaction & Expected $\mathrm{Nr}$ & Observation $\mathrm{Nr} n$ & $\chi^{2}(3: 1)$ & $\mathrm{P}$ \\
\hline $\mathrm{F}_{2}$ & Resistance $(\mathrm{R})$ & 259 & 250 & 0.29 & \\
& Susceptible (S) & 86 & 95 & 0.89 & \\
& Total plant & 345 & 345 & 1.18 & 0.3055
\end{tabular}

$\mathrm{df}=1.0 ; \chi^{2}=3.84$ 
To have a comprehensive understanding of the molecular mechanism for broad-spectrum resistance to rice BLB and for further confirmation report result, additional genetics studies are needed to investigate whether quantitative and qualitative genes affect the level of the resistance in rice 'IRBB60'. As reported by Ashkani et al. (2011), application of MAS in rice have shown that the use of tightly linked DNA markers to targeted genes can be identified more efficiently in a segregating population at any plant growth stage. Molecular MAS background analysis of segregates is convenient in determining the relation contribution of the progenitor parents. In addition, the finding of Sanchez et al. (2000) revealed the effectiveness of MAS in gene pyramiding for BLB R-gene, mostly for recessive genes, such as $x a 13$ and $x a 5$ that are challenging to select as compared with the conventional background in the existence of a dominant gene such as $\mathrm{Xa21}$. Hence, pyramiding multiple resistance genes in a single rice cultivar is recommended as a strategy to delay or prevent the breakdown of resistance. The disposition of rice varieties that have multiple BLB R-genes is predictable to lead to more durable resistance (Salgotra et al., 2012). As reported by Chukwu et al. (2019b), the possibility of coincident pathogen transformations for virulence to overcome the resistance conferred by two or more effective genes is much lower than for a single gene.

\section{CONCLUSIONS}

In this study, genotypic analyses on 18 polymorphic SSR markers were identified. Among the polymorphic markers, the chi-square analyses showed that 15 SSR markers had a segregation ratio of 1:2:1. Phenotypic data based on disease reaction of resistance and susceptibility to bacterial leaf blight (BLB) Xanthomonas oryzae pv. oryzae pathotype Xoo $\mathrm{P}_{7.0}$ also segregated in a 3:1 (R:S) ratio in the $\mathrm{F}_{2}$ population. Therefore, resistance to BLB pathotype Xoo $\mathrm{P}_{7.0}$ in 'IRBB60' is more likely controlled by a single dominant gene. These markers RM13 (xa5), RM21 (Xa21), RM122 (xa5), RM153 (xa5), RM164 (Xa13), RM206 (Xa10), RM5509, RM20B, RM25, RM163, RM169, RM218, RM267, RM276, and RM334 offer a potential, fast, easy and consistent method in MAS for screening BLB in future breeding programs. Molecular marker analysis with SSR markers gives a quick evaluation of the genetic background of the recombinant. This is a successful example of applying an integrated approach to plant breeding. MAS was used for identifying plants with multiple BLB R-genes and conventional phenotypic selection for recovering 'MR219' quality traits. In addition, SSR based background analysis helped in determining the amount of 'MR219' alleles in the combination that influenced desirable traits from 'IRBB60', such as BLB resistance and increase the grain yield. These studies are expected to have a high impact on the yield steadiness and sustainability of Malaysia rice production.

\section{ACKNOWLEDGEMENTS}

The authors are grateful to Malaysian Agriculture Research and Development Institute and the Ministry of Education Malaysia, for adequate research funding through the Higher Institutions Centre of Excellence (HICoE) to conduct research on improvement of rice varieties.

\section{REFERENCES}

Ashkani, S., Rafii, M.Y., Rusli, I., Sariah, M., Abdullah, S.N.A., Rahim, H.A., et al. 2012. SSRs for marker-assisted selection for blast resistance in rice (Oryza sativa L.) Plant Molecular Biology Reporter 30(1):79-86.

Ashkani, S., Rafii, M.Y., Sariah, M., Siti, N.A.A., Rusli, I., Harun, A.R., et al. 2011. Analysis of simple sequence repeat markers linked with blast disease resistance genes in a segregating population of rice (Oryza sativa). Genetics and Molecular Research 10(3):1345-1355.

Bashar, Z.U., Wayayok, A., and Soom Mohd, A.M. 2014. Determination of some physical properties of common Malaysian rice MR219 seeds. Australian Journal of Crop Science 8(3):332-337.

Chu, Z., Yuan, M., Yao, J., Ge, X., Yuan, B., Xu, C., et al. 2006. Promoter mutations of an essential gene for pollen development result in disease resistance in rice. Genes \& Development 20(10):1250-1255.

Chukwu, S.C., Rafii, M.Y., Ramlee, S.I., Ismail, S.I., Hasan, M.M., Oladosu, Y.A., et al. 2019a. Bacterial leaf blight resistance in rice: a review of conventional breeding to molecular approach. Molecular Biology Reports 46(1):1519-1532.

Chukwu, S.C., Rafii, M.Y., Ramlee, S.I., Ismail, S.I., Oladosu, Y., Okporie, E., et al. 2019b. Marker-assisted selection and gene pyramiding for resistance to bacterial leaf blight disease of rice (Oryza sativa L.) Biotechnology \& Biotechnological Equipment 33(1):440-455. 
IRRI. 2002. Standard evaluation system for rice. p. 1-45. International Rice Research Institute (IRRI), Los Baños, Laguna, Philippines.

Iyer-Pascuzzi, A.S., and McCouch, S.R. 2007. Functional markers for xa5-mediated resistance in rice (Oryza sativa, L.) Molecular Breeding 19(4):291-296.

Kauffman, H.E., Kauffman, H.E., Reddy, A.P.K., Hsieh, S.P.Y., and Merca, S.D. 1973. An improved technique for evaluating resistance of rice varieties to Xanthomonas oryzae. Plant Disease Report 57:537-541.

McCouch, S.R., Sebastian, L.S., Ikeda, R., Huang, N., Imbe, T., and Coffman, W.R. 1996. Molecular mapping of resistance to rice tungro spherical virus and green leafhopper. Phytopathology 86:25-30.

Oladosu, Y., Rafii, M.Y., Abdullah, N., Abdul Malek, M., Rahim, H.A., Hussin, G., et al. 2014. Genetic variability and selection criteria in rice mutant lines as revealed by quantitative traits. The Scientific World Journal 2014:190531.

Oladosu, Y., Rafii, M.Y., Abdullah, N., Malek, M.A., Rahim, H.A., Hussin, G., et al. 2015. Genetic variability and diversity of mutant rice revealed by quantitative traits and molecular markers. Agrociencia 49(3):249-266.

Oladosu, Y., Rafii, M.Y., Magaji, U., Abdullah, N., Miah, G., Chukwu, S.C., et al. 2018. Genotypic and phenotypic relationship among yield components in rice under tropical conditions. BioMed Research International 2018:8936767.

Rafidah, A.R., Norhafniza, A., Faridah, S., and Asfaliza, R. 2018. Bacteria leaf blight disease of rice: Characterisation of pathogen and polyclonal antibody production of Xanthomonas oryzae pv. oryzae. Transactions of the Malaysian Society of Plant Physiology 25:247-252.

Ram, T., Laha, G.S., Gautam, S.K., Deen, R., Madhav, M.S., Brar, D.S., et al. 2010. Identification of new gene introgressed from Oryza brachyantha with broad-spectrum resistance to bacterial blight of rice in India. Rice Genetics Newsletter 25:57-58.

Salgotra, R.K., Gupta, B.B., Millwood, R.J., Balasubramaniam, M., and Stewart, C.N. 2012. Introgression of bacterial leaf blight resistance and aroma genes using functional marker-assisted selection in rice (Oryza sativa L.) Euphytica 187(3):313-323.

Sanchez, A.C., Brar, D.S., Huang, N., Li, Z., and Khush, G.S. 2000. Sequence tagged site marker-assisted selection for three bacterial blight resistance genes in rice. Crop Science 40(3):792-797.

Shanti, M.L., Devi, G.L., Kumar, G.N., and Shashidhar, H. 2010. Molecular marker-assisted selection: a tool for insulating parental lines of hybrid rice against bacterial leaf blight. International Journal of Plant Pathology 1:114-123.

Singh, S., Sidhu, J.S., Huang, N., Vikal, Y., Li, Z., Brar, D.S., et al. 2001. Pyramiding three bacterial blight resistance genes $(x a 5, x a 13$ and $\mathrm{Xa21}$ ) using marker-assisted selection into indica rice cultivar PR106. Theoretical and Applied Genetics 102:1011-1015.

Yasmin, S., Hafeez, F.Y., Mirza, M.S., Rasul, M., Arshad, H.M., Zubair, M., et al. 2017. Biocontrol of bacterial leaf blight of rice and profiling of secondary metabolites produced by rhizospheric Pseudomonas aeruginosa BRp3. Frontiers in Microbiology 8:1895. 